\title{
Occurrence of Togninia minima Perithecia in Esca-Affected Vineyards in California
}

\author{
S. Rooney-Latham, A. Eskalen, and W. D. Gubler, University of California-Davis, Department of Plant Pathology, \\ Davis 95616
}

\begin{abstract}
Rooney-Latham, S., Eskalen, A., and Gubler, W. D. 2005. Occurrence of Togninia minima perithecia in esca-affected vineyards in California. Plant Dis. 89:867-871.

Togninia minima is an important pathogen causing esca and grapevine declines worldwide. Although perithecia of T. minima have been produced in the laboratory, their presence in diseased vineyards has not been shown. In our study, perithecia of $T$. minima were found on grapevines in the field in five California counties. Perithecia were clustered on dead vascular tissue in deep cracks along trunks and cordons or on the surfaces of decayed pruning wounds. Field-collected perithecia were characteristic of T. minima perithecia previously produced in vitro and molecular sequence analysis of the internal transcribed spacer region of the nuclear ribosomal DNA additionally confirmed their identity. Ascospores from perithecia germinated on agar medium and formed colonies typical of T. minima. This is the first report of $T$. minima perithecia in diseased vineyards and suggests ascospores as an additional source of inoculum for new grapevine infections.
\end{abstract}

Additional keywords: black measles, Petri disease, Vitis vinifera

Togninia minima (Tul. and C. Tul) Berl., the teleomorph of the asexual fungus Phaeoacremonium aleophilum W. Gams, Crous, M. J. Wingfield and L. Mugnai, is one of the causal agents of esca (black measles) and young vine decline (Petri disease) of grapevines in California $(1,4,21,28,32)$. Both diseases occur worldwide, inflicting significant economic damage to both table and wine grape cultivars $(30,31)$. Historically, esca develops in mature grapevines. However, in the past decade, disease incidence on younger grapevines ( 2 to 3 years old) has increased considerably and stimulated renewed research interest $(30,31)$.

Symptoms of esca include a reduction in trunk diameter, black vascular streaking, interveinal foliar chlorosis or reddening often resulting in a "tiger stripe" pattern on the leaves (Fig. 1A), shoot tip dieback in early spring (Fig. 1B), and spotting or raisining of the berries (Fig. 1C). Often, yields are reduced and the fruit is unmarketable $(22,30,31)$. Young vine decline occurs on immature grapevines and is characterized by stunted shoot growth, shortened internodes, leaf chlorosis, and vascular plugging causing discoloration of the woody cylinder (Fig. 1D; 30,31).

Corresponding author: W. D. Gubler

E-mail: wdgubler@ucdavis.edu

Accepted for publication 6 April 2005

DOI: 10.1094/PD-89-0867

(C) 2005 The American Phytopathological Society
Other fungi associated with esca and vine decline include Phaeomoniella chlamydospora Crous and Gams and other species of Phaeoacremonium $(3,4,12)$. Phaeomoniella chlamydospora has been implicated as the primary pathogen responsible for Petri disease of young grapevines although, in California, similar dis-
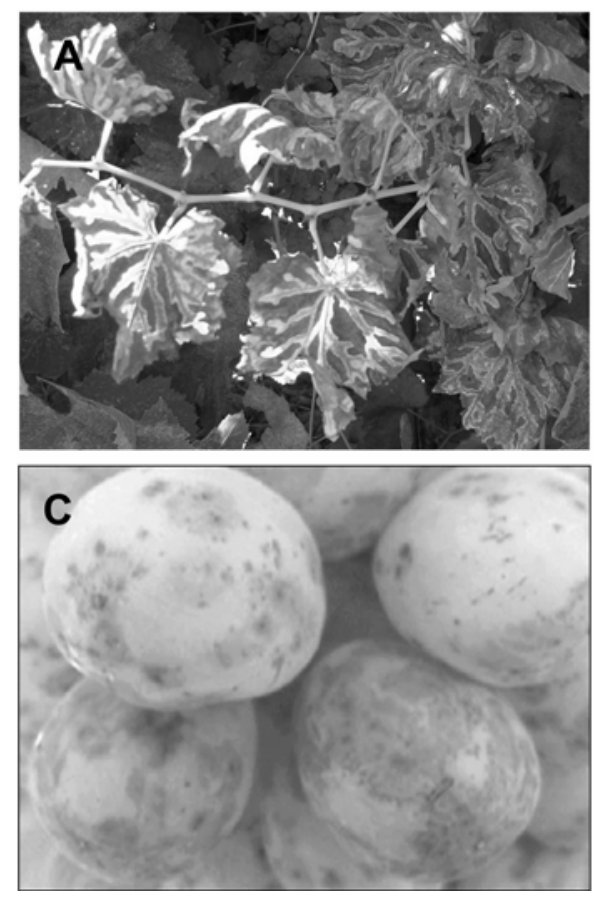

Fig. 1. Grapevines infected by Togninia minima and showing typical esca symptoms. A, "Tiger striped" patterns on leaves of Vitis vinifera cv. Thompson Seedless, B, tip dieback developed in early spring, C, spotting or "measles" on Thompson Seedless berries, and $\mathbf{D}$, cross section of the trunk of a young grapevine with dark vascular streaking.
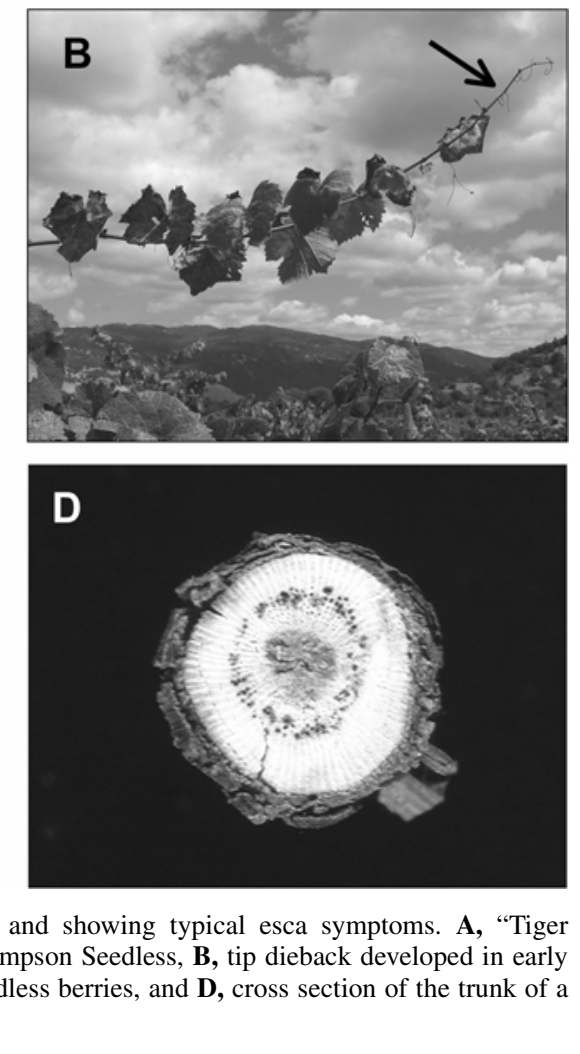

ease symptoms developed on young plants inoculated with conidia of Phaeoacremonium aleophilum (30,31). Though there is debate around the world regarding the number of fungal species involved in esca, pathogenicity tests with $T$. minima (P. aleophilum) clearly demonstrate a causal relationship with esca in California (13,27).

T. minima (Diaporthales) recently was confirmed as the sexual stage of $P$. aleophilum after in vitro pairings between compatible isolates $(21,24,26,28,29)$. The pairings demonstrated that T. minima is heterothallic and that both mating types can be found in the same vineyard and on the same vine $(21,23,28)$. Perithecia also were observed in California and Australia on infected grapevine wood pieces after 2 to 5 months of moist incubation in the laboratory $(23,28)$, further suggesting the possibility of sexual reproduction in nature. The occurrence of $T$. minima perithecia in diseased vineyards, however, has not been documented prior to this report.

The infection process of the two primary esca pathogens is unclear. However, recovery of Phaeomoniella chlamydospora and T. minima from nursery stock and young 
grapevines suggests that infections can occur from propagation of diseased plant sources $(7,34)$. Even so, Gubler et al. (13) demonstrated that pruning wounds were susceptible to infection by conidia of both Phaeoacremonium aleophilum and Phaeomoniella chlamydospora for up to 4 months. Additionally, Larignon et al. (19) showed that pruning wound susceptibility was dependent on pruning date, and wounds were receptive for 8 to 9 weeks in French vineyards. At the time these studies were done, the asexual stage was unknown and, therefore, conidia of Phaeoacremonium aleophilum rather than T. minima ascospores were used as inoculum.

In California, it has been shown that spores of T. minima and Phaeomoniella chlamydospora are aerially dispersed in infested California vineyards, mostly during the winter and spring. However, the trapping study did not identify whether the trapped propagules were ascospores or conidia $(8,9,20)$. We suspect ascospores were the propagule type trapped, because asexual fruiting structures of Phaeoacremonium spp. never have been observed on artificial media or on grapevines in California, nor have they been reported in other parts of the world. Propagules of both Phaeomoniella chlamydospora and $T$. minima were trapped throughout California and their release was closely associated with rainfall although, during the summer, $T$. minima spores also were trapped sporadically without rainfall $(8,9,20)$. The sources of aerial $P$. chlamydospora spores were pycnidia embedded in dead vascular tissue of 3- to 5-year-old pruning wounds on diseased grapevines $(5,6,11)$. Although spores of $T$. minima were recovered from soil, standing water, and on the woody nor spore type was identified $(10,25)$.

In a recent study documenting ascospore release of $T$. minima, it was suggested that aerially dispersed ascospores were the propagules trapped in previous studies (27). Using cinephotomicrography, it was shown that, after thorough wetting, T. minima ascospores can be discharged forcibly from perithecia produced in vitro. Ascosurfaces of grapevines, neither the source

spore release of $T$. minima in vineyards probably is similar to that of Eutypa lata. Following rainfall, ascospores of E. lata are released from perithecia found on old infected wood. These ascospores are aerially dispersed and land on fresh grapevine pruning wounds, causing new infections. Conidia of E. lata are considered insignificant in the disease (2). The purpose of this research was to determine whether $T$. minima perithecia in fact do occur naturally in California vineyards.

\section{MATERIALS AND METHODS}

Collection and manipulation of grapevine material. Full-production vineyards where propagules of T. minima were detected previously in spore traps were surveyed for perithecia in summer 2004. Vineyards were located in five different California counties and included both wine and table grape cultivars. Symptomatic grapevine trunks, cordons, and spurs were collected from the vineyards and brought back to the laboratory for analysis.

The hardwood grapevine samples were cut into small (20 cm long) pieces and split longitudinally, exposing the vascular tissues. Twenty-five pieces from each vineyard were placed individually in clean plastic bags, sprayed with $30 \mathrm{ml}$ of sterile distilled water, and incubated at room temperature $\left(23 \pm 3^{\circ} \mathrm{C}\right)$ for approximately 10 to $15 \mathrm{~min}$. The pieces then were air dried before storing them in a clean plastic bag at $10^{\circ} \mathrm{C}$. Washing solutions were collected and forcibly passed through 5- and 0.45$\mu \mathrm{m}$-pore-size syringe filters (Pall Corporation; East Hills, NY) attached in tandem to sterile 35-ml syringes (Monoject, Sherwood Medical Supply, St. Louis). The 5$\mu \mathrm{m}$ filters trapped debris and large fungal spores. The $0.45-\mu \mathrm{m}$ filters trapped small particulates and smaller spores, including those of T. minima. The filters were rinsed with $1 \mathrm{ml}$ of sterile water to backwash any trapped spores. The solutions were collected in 1.5-ml microfuge tubes and 200$\mu \mathrm{l}$ aliquots then were spread onto potato dextrose agar (Difco; BD Microbiology Systems, Franklin Lakes, NJ) amended with $0.01 \%$ tetracycline hydrochloride

Table 1. Occurrence of Togninia minima perithecia in California vineyards and GenBank accession numbers of cultures

\begin{tabular}{lllll}
\hline Vineyard & Location (county) & \multicolumn{1}{c}{ Variety } & Perithecia $^{\mathbf{a}}$ & Accession $^{\mathbf{b}}$ \\
\hline 1 & Madera & Thompson & NC & AY7866143 \\
& $\ldots$ & Seedless & $\ldots$ & $\ldots$ \\
2 & Madera & Thompson & NC & $\ldots$ \\
3 & $\ldots$ & Seedless & NC & $\ldots$ \\
& Fresno & Thompson & $\ldots$ & $\ldots$ \\
4 & $\ldots$ & Seedless & NC, PW & $\ldots$ \\
& $\ldots$ & Thompson & $\ldots$ & $\ldots$ \\
5 & $\ldots$ & Seedless & NC, PW & $\ldots$ \\
6 & Mendocino & Riesling & NC & $\ldots$ \\
\hline
\end{tabular}

${ }^{\mathrm{a}}$ Location of perithecia in vascular tissue of $\mathrm{NC}=$ trunk and cordon cracks and $\mathrm{PW}=$ pruning wound surfaces.

${ }^{\mathrm{b}}$ GenBank internal transcribed spacer accession from single-ascospore cultures.
(PDA-tet). Plates were air dried in a laminar flow hood with lids partially lifted for 30 min. Plates then were sealed with parafilm and incubated at room temperature for 7 days, after which they were examined for Phaeoacremonium aleophilum colonies.

Grapevine pieces which had shown the presence of $T$. minima propagules were examined thoroughly for T. minima fruiting structures under a stereomicroscope. Perithecia resembling those of $T$. minima were located, measured, and photographed before being crushed in sterile water and plated (as above). Ascospores and asci also were photographed and plated to examine colony morphology. In addition, fieldcollected perithecia were placed in drops of sterile water on glass slides and examined under a compound microscope to observe ascospore release.

Suspect T. minima perithecia were examined further with scanning electron microscopy (SEM) at the University of California-Davis Microscopy and Imaging Facility. Grapevine samples containing perithecia were vacuum dried overnight using a Denton Bench Top Turbo III vacuum evaporator (Denton Vacuum, Moorestown, NJ) before being gold-coated with a Denton Desk II cold sputter coater (Denton Vacuum). The samples were examined using a Hitachi S-3500N scanning electron microscope (Hitachi High-Technologies; Tokyo) operated at 2.00 and $5.00 \mathrm{kV}$.

DNA extraction, polymerase chain reaction amplification, and molecular sequence analysis. Two single-ascospore isolates collected from perithecia from two different vineyards were cultured on malt extract agar (Difco; BD Microbiology Systems) for 7 days. DNA was extracted from fungal mycelia using an AquaPure Genomic DNA Kit (Bio-Rad Laboratories; Hercules, CA). Oligonucleotide primers internal transcribed spacer (ITS) 4 and ITS5 (33) were used to amplify the ITS region of the nuclear ribosomal DNA, including the $5.8 \mathrm{~S}$ gene. Amplification reactions in a total volume of $50 \mu \mathrm{l}$ were performed on a PTC-200 System (MJ Research, Inc., Waltham, MA). Cycling conditions included an initial denaturation for 2 min at $94^{\circ} \mathrm{C}$, followed by 35 cycles of denaturation $\left(94^{\circ} \mathrm{C}\right)$ for $60 \mathrm{~s}$, annealing $\left(58^{\circ} \mathrm{C}\right)$ for $60 \mathrm{~s}$, and extension $\left(72^{\circ} \mathrm{C}\right)$ for $90 \mathrm{~s}$. A final extension was performed at $72^{\circ} \mathrm{C}$ for 5 min. Polymerase chain reaction (PCR) products were purified using a QIAquick PCR Purification Kit (Qiagen, Hilden, Germany) and sequenced at the University of California-Davis DNA Sequencing Facility using an ABI 3730 Capillary Electrophoresis Genetic Analyzer and BigDye Terminator v3.1 Cycle Sequencing Kit with AmpliTaq DNA Polymerase (Applied Biosystems; Foster City, CA). Sequences were deposited in GenBank after being compared with previously deposited T. minima GenBank sequences (Table 1). 
Collection and manipulation of grapevine material. Filtrates from grapevine washings cultured on PDA-tet media produced fungal colonies characteristic of lum, after 7 days. Perithecia similar in size and shape to T. minima produced in culture were observed on grapevine pieces containing $T$. minima propagules. These perithecia developed superficially or partially embedded in host tissue. Perithecia typically were found in the decayed xylem tissues of old pruning wounds or inside deep cracks along trunks, cordons, and

\section{RESULTS} T. minima or its asexual state, P. aleophi-

spurs (Fig. 2A and B). Perithecia were identified on three Vitis vinifera cultivars (Thompson Seedless, Riesling, and Cabernet Sauvignon) in six vineyards in five California counties.

Field collections of $T$. minima perithecia produced on woody grapevine tissues were black, globose to subglobose, and ranged in diameter from 200 to $280 \mu \mathrm{m}$ (Fig. 3AC). Although many of the perithecial necks were broken, intact necks ranged in length from 275 to $880 \mu \mathrm{m}$ and often branched or occurred in multiples of 2 or 3 per perithecium (Fig. 3D). The necks of most perithecia borne deep within the trunks and cor-
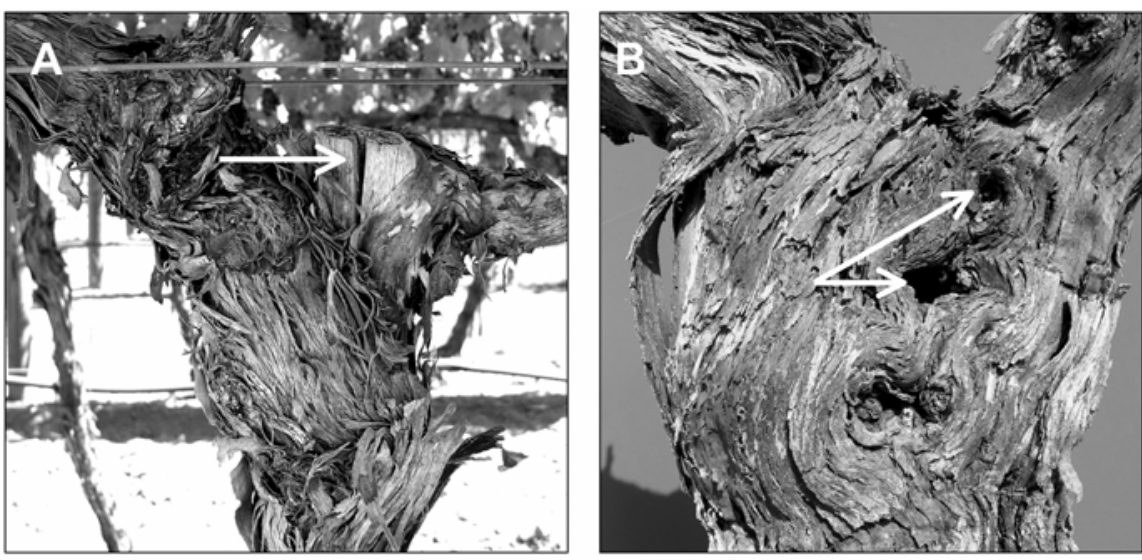

Fig. 2. Diseased grapevines with perithecia found on dead vascular tissue of $\mathbf{A}$, cracked pruning wound (arrow) and $\mathbf{B}$, natural wounds and cavities (arrows) of a trunk.
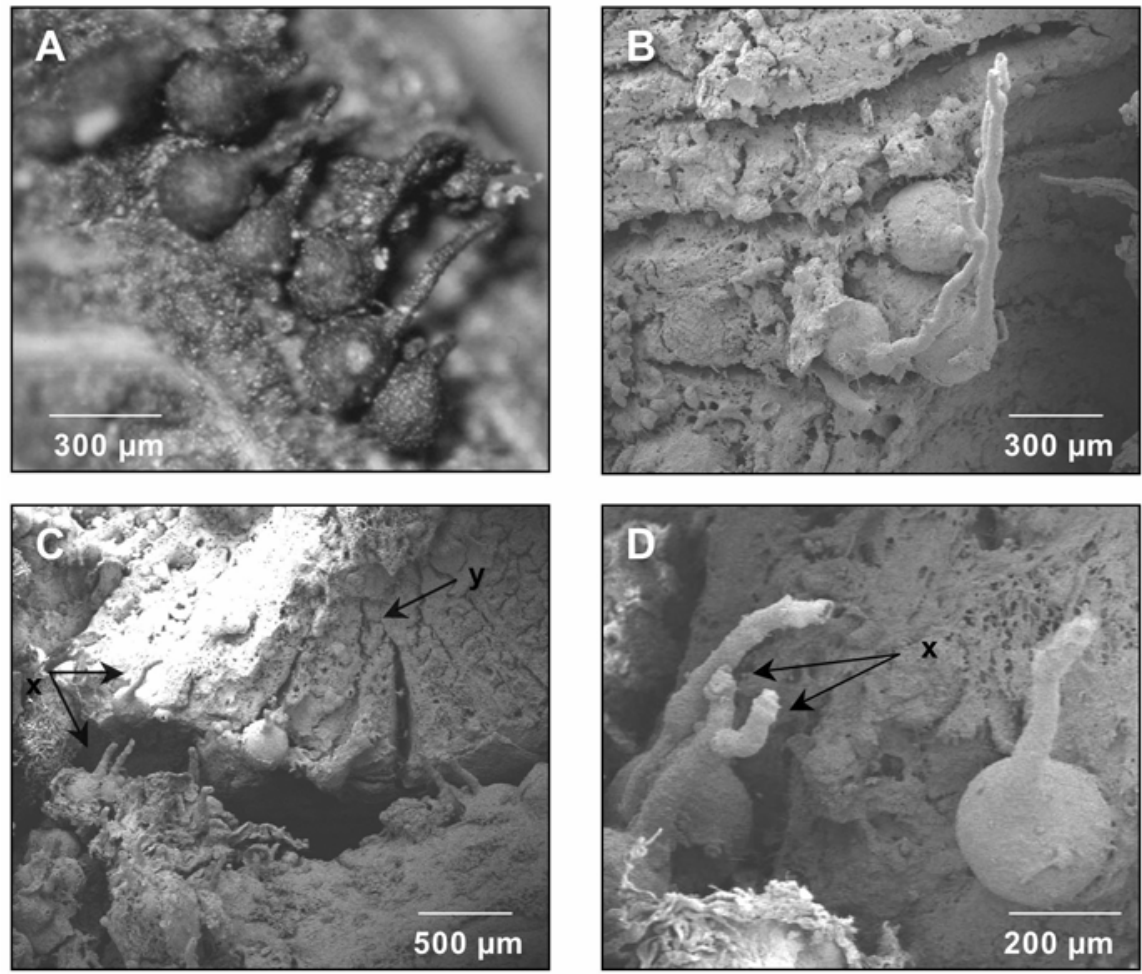

Fig. 3. Dissecting microscope and scanning electron microscope (SEM) photographs of Togninia minima perithecia on vascular tissue of grapevines from Mendocino, Yolo, and Madera counties. A, $T$. minima perithecia clustered in a grapevine crack, $\mathbf{B}$, SEM photograph of perithecia with necks exhibiting phototropism, C, SEM photograph of T. minima perithecia (x) on the surface (y) of a pruning wound, and D, SEM photograph of a perithecium with a branched neck (arrows). dons were oriented toward the surface, suggesting phototropic sensitivity (Fig. 3B). Asci were hyaline and clavate and ranged in length from 17.1 to $23.4 \mu \mathrm{m}$ and in width from 3.9 to $5.1 \mu \mathrm{m}$, (Fig. 4). Ascospores were hyaline, biguttulate, and ellipsoid to allantoid and ranged in size from 4.1 to 5.1 by 1.3 to $2.0 \mu \mathrm{m}$ (Fig. 4). When plated onto PDA-tet media, ascospores formed colonies typical of $T$. minima (P. aleophilum) after 7 days. When field-collected perithecia were remoistened, asci exuded from the perithecial ostiole after approximately 30 to $45 \mathrm{~min}$. Upon exiting the ostiole, asci either accumulated in groups around the perithecial neck or forcibly discharged ascospores.

DNA extraction, PCR amplification, and molecular sequence analysis. ITS sequences (including the $5.8 \mathrm{~S}$ gene) of colony mycelia derived from germinating single ascospores (GenBank accessions AY786142 and AY786143) from vineyard sites 1 and 3 (Table 1) were identical among the 538 nucleotides to GenBank sequences of California $T$. minima isolates (AY644480 and AY644479) and the type specimen of $P$. aleophilum (AF266647), confirming the identity of these perithecia as T. minima.

\section{DISCUSSION}

Perithecia were discovered on grapevines exhibiting symptoms of esca in vineyards located throughout California. They were identified as $T$. minima based on perithecium morphology, colony growth on artificial medium, and nucleotide sequences of the ITS region of the nuclear ribosomal DNA. Later comparisons to type and nontype $T$. minima GenBank sequences of the ITS region including the 5.8S gene were identical. T. minima perithecia collected in vineyards were typical of those produced in vitro. Sizes of perithecia, perithecial necks, asci, and ascospores also were within the established range for those produced in vitro $(21,28)$. Ascospore release of moistened field-collected perithecia, including forcible discharge, was similar to that which was observed by Latham et al. (20) and Rooney-Latham et al. (27) with moistened

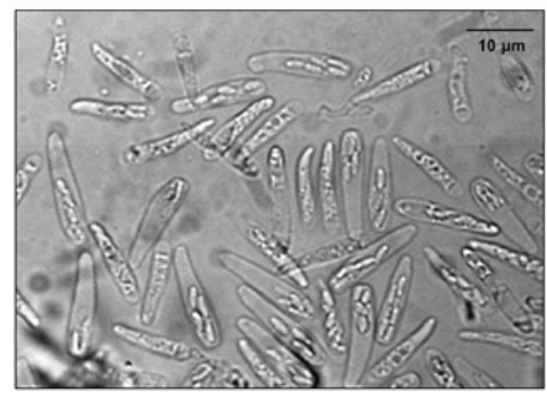

Fig. 4. Squash mount of a crushed Togninia minima perithecium releasing its content of oblong to clavate asci and one-celled, hyaline, allantoid, biguttulate ascospores. 
perithecia produced in vitro. This further suggests occurrences of ascospore release following precipitation in infested vineyards.

Predictions by both Pascoe et al. (23) and Rooney-Latham et al. (28) that T. minima perithecia eventually would be found in naturally infected vineyards were correct. Pascoe et al. (23) suggested that their natural occurrence likely would be on or in crevices of infected dead grapevine wood, after successfully producing perithecia on naturally infected wood incubated at high humidity in the laboratory. RooneyLatham et al. (28) also observed perithecia on naturally infected, moist, incubated grapevine wood in the laboratory and speculated about their occurrence on exposed grapevine vascular tissue, specifically wounds made during pruning and girdling. Although they were seen sporadically on the surfaces of grapevine pruning wounds in our survey, T. minima perithecia typically occurred in cracks and crevices associated with pruning wounds or those made from natural drying of the grapevine wood. Perithecia were observed in nearly every vineyard that was surveyed and were seen only on decayed vascular tissue. Field-collected perithecia, however, did not exhibit ascospore accumulation as droplets at their perithecial neck tips. Although this commonly occurs with in vitro-produced perithecia, its absence among our field-collected perithecia may be due to the time during which the survey was conducted. Perithecia were collected only in the arid summer months, which may be unfavorable for this method of ascospore release.

The discovery of $T$. minima perithecia in vineyards, in addition to the absence of any recognized asexual $P$. aleophilum fruiting bodies, suggests that the aerial propagules that have been captured on spore traps in California vineyards are, in fact, ascospores $(8,19,20)$. The ability of $T$. minima asci to forcibly discharge ascospores after thorough wetting may explain the large numbers of $T$. minima spores that are trapped following rain in California. The sporadic capture of small numbers of T. minima spores in dry summer months may be attributed to overhead irrigation in these vineyards $(8,20,27)$. Overhead sprinkler irrigation has been linked to spore release of other grapevine fungal pathogens, including Phomopsis viticola and Uncinula necator $(14,16)$. Fungal propagules of $T$. minima have also been recovered from small pools of water created by drip line emitters beneath the canopy (25). These pools of water usually contained old decayed grapevine wood, suggesting that infested debris left in the vineyard after pruning also may serve as a source of inoculum.

Although unproven experimentally, wood-boring insects may have an incidental role in the spread of T. minima. Asco- mata of closely related $T$. fraxinopennsylvanica have been identified in larval galleries of Fraxinus pennsylvanica in North Dakota (17) and, more recently, on dead vascular tissue of declining Fraxinus spp. and grapevines in California (A. Eskalen, unpublished). Additionally, Phaeoacremonium rubrigenum, another Phaeoacremonium sp. sporadically isolated from diseased grapevines, was isolated from larvae and their galleries on Fraxinus and Quercus spp. (18). In our study, perithecia often were clustered inside cracks and insect tunnels in grapevines, supporting a putative association with insect dispersal of T. minima spores.

Previous research clearly demonstrated that $T$. minima ascomata produced in vitro exhibit phototropic behavior (23) and that light is necessary for perithecia formation (28). However, perithecia rarely were identified on surfaces of grapevines and usually formed in deep cracks and wounds. The necks of these perithecia invariably were oriented toward openings of bark cracks, pruning wounds, and insect tunnels. These results support previous work (27) which indicated that, after precipitation, ascospores are forcibly discharged from perithecia through openings and carried in wind currents or, possibly, by insects to new wound sites. This may be the way in which new grapevine scion infections occur, because we recently showed that $T$. minima ascospores can effectively colonize fresh grapevine pruning wounds (unpublished).

Although T. minima may be present in plants propagated from diseased canes $(7,34)$, our research demonstrates an abundance of fungal inoculum within California vineyards which previously was unrecognized. We suspect that $T$. minima perithecia occur worldwide, because both mating types also have been reported within vineyards and on the same vine in South Africa and Australia (21,23). Their minute size and occurrence primarily inside cracks on dead vascular tissue may explain why they have not been identified previously.

Currently, there are no known measures for prevention of esca or Petri disease in established vineyards. Our discovery, however, pinpoints inoculum source sites within vineyards, which may eventually lead to the formulation of disease management strategies. Examples of such strategies may include the use of dormant spray applications and pruning wound protectants, as well as careful timing of vineyard pruning. Dormant spray applications have been used successfully to manage grapevine diseases such as Phomopsis cane and leaf spot and powdery mildew $(14,16)$. Successful management strategies of Eutypa dieback of grapevines, also caused by a fungal pathogen that releases ascospores after rainfall, include delayed or double vineyard prun- ing as well as the use of various wound protectants (15).

\section{LITERATURE CITED}

1. Berlese, A. N. 1900. Icones fungorum omnium hucusque cognitorum. Patavia 3:9-21.

2. Carter, M. V. 1991. The status of Eutypa lata as a pathogen. Monogr. Phytopathol. Pap. No. 32. International Mycological Institute, Surrey, UK.

3. Crous, P. W., and Gams, W. 2000. Phaeomoniella chlamydospora gen. et comb. Nov., a causal organism of Petri grapevine decline and esca. Phytopathol. Mediterr. 39:112-118.

4. Crous, P. W., Gams, W., Wingfield, M. J., and van Wyk, P. S. 1996. Phaeoacremonium gen. nov. associated with wilt and decline disease of woody host and human infection. Mycologia 88:786-796.

5. Edwards, J., and Pascoe, I. G. 2001. In situ sporulation of Phaeomoniella chlamydospora in the vineyard. Phytopathol. Mediterr. 40:6166.

6. Edwards, J., and Pascoe, I. G. 2001. Pycnidial state of Phaeomoniella chlamydospora found on Pinot noir grapevines in the field. Australas. Plant Pathol. 30:67.

7. Edwards, J., Pascoe, I., Salib, S., and Laukart, N. 2004. Phaeomoniella chlamydospora and Phaeoacremonium aleophilum can spread into grapevine canes from trunks of infected mother vines. Twelfth Australian Wine Industry Technical Conference, Melbourne, Victoria, Australia.

8. Eskalen, A., and Gubler, W. D. 2001. Association of spores of Phaeomoniella chlamy dospora, Phaeoacremonium inflatipes and $\mathrm{Pm}$. aleophilum with grapevine cordons in California. Phytopathol. Mediterr. 40:S429-432.

9. Eskalen, A., Latham, S. R., and Gubler, W. D. 2004. Spore release of Phaeomoniella chlamydospora associated with grapevine cordons in California. (Abstr.) Phytopathology 94:S28.

10. Eskalen, A., Rooney-Latham, S., Feliciano, A. J., and Gubler, W. D. 2004. Epiphytic occurrence of esca and Petri disease pathogens on grapevine tissue. Phytopathol. Mediterr. 43:154.

11. Eskalen, A., Rooney, S. N., and Gubler, W. D. 2002. First report of the pycnidial state of Phaeomoniella chlamydospora, a causal agent of black measles (esca) and Petri disease in California vineyards. (Abstr.) Phytopathology 92:S24.

12. Groenwald, M. Kang, J. Crous, P. W., and Gams, W. 2001. ITS and B-tubulin phylogeny of Phaeoacremonium and Phaeomoniella species. Mycol. Res. 105:651-657.

13. Gubler, W. D., Eskalen, A., Feliciano, A. J., and Khan, A. 2001. Susceptibility of grapevine pruning wounds to Phaeomoniella chlamydospora and Phaeoacremonium spp. Phytopathol. Mediterr. 40:S482-483.

14. Gubler, W. D., and Hirschfelt, D. J. 1992. Powdery mildew. Pages 57-62 in: Grape Pest Management, 2nd ed. D. L. Flaherty, L. P. Christensen, W. T. Lanini, J. J. Marois, P. A Phillips, and L. T. Wilson, eds. The Regents of the University of California; Division of Agriculture and Natural Resources, Oakland.

15. Gubler, W. D., and Leavitt, G. M. 1992. Eutypa dieback of grapevines. Pages 71-75 in: Grape Pest Management, 2nd ed. D. L. Flaherty, L. P. Christensen, W. T. Lanini, J. J. Marois, P. A. Phillips, and L. T. Wilson, eds The Regents of the University of California; Division of Agriculture and Natural Resources, Oakland.

16. Gubler, W. D., and Leavitt, G. M. 1992. Phomopsis cane and leaf spot. Pages 85-88 in: Grape Pest Management, 2nd ed. D. L. Flaherty, L. P. Christensen, W. T. Lanini, J. J. Marois, P. A. Phillips, and L. T. Wilson, eds. 
The Regents of the University of California; Division of Agriculture and Natural Resources, Oakland.

17. Hausner, G., Eyjolfsdottir, G., and Reid, J. 1991. Two additional species of the genus Togninia. Can. J. Bot. 70:724-734.

18. Kubatova, A., Kolarik, M., and Pazoutova, S. 2004. Phaeoacremonium rubrigenum-hyphomycete associated with bark beetles found in Czechia. Folia Microbiol. 49:99-104.

19. Larignon, P. 1999. Esca disease from a European perspective. Pages 43-55 in: Black Goo: Symptoms and Occurrence of Grapevine Declines. L. Morton, ed. International Ampelography Society, Fort Valley, VA.

20. Latham, S. R., Eskalen, A., and Gubler, W. D. 2004. Ascospore discharge and occurrence of Togninia minima (anamorph $=$ Phaeoacremonium aleophilum) in California vineyards. (Abstr.) Phytopathology 94:S57.

21. Mostert, L. P., Crous, P. W., Groenwald, J., Gams, W., and Summerbell, R. C. 2003. Togninia (Calosphaeriales) is confirmed as the teleomorph of Phaeoacremonium by means of morphology, sexual compatibility and DNA phylogeny. Mycologia 95:646-659.

22. Mugnai, L., Graniti, A., and Surico, G. 1999. Esca (black measles) and brown wood streaking: two old and elusive diseases of grapevines. Plant Dis. 83:404-417.
23. Pascoe, I. G., Edwards, J., Cunnington, J. H., and Cottral, E. H. 2004. Detection of the Togninia teleomorph of Phaeoacremonium aleophilum in Australia. Phytopathol. Mediterr. 43:51-58.

24. Reblova, M., Mostert, L., Gams, W., and Crous, P. W. 2004. New genera in the Calosphaeriales: Togniniella and its anamorph Phaeocrella, and Calosphaeriophora as anamorph of Calosphaeria. Stud. Mycol. 50:533-550.

25. Rooney, S. N., Eskalen, A., and Gubler, W. 2001. Recovery of Phaeomoniella chlamydospora and Phaeoacremonium inflatipes from soil and grapevine tissues. Phytopathol. Mediterr. 40: S351-356.

26. Rooney, S. N., Eskalen, A., and Gubler, W. D. 2003. First report of the teleomorph of Phaeoacremonium spp., the cause of esca and decline of grapevines. (Abstr.) Phytopathology 93:S129.

27. Rooney-Latham, S., Eskalen, A., and Gubler, W. D. 2005. Ascospore release of Togninia minima, cause of esca and grapevine decline in California. Online. Plant Health Progress DOI: 10.1094/PHP-2005-0209-01-RS.

28. Rooney-Latham, S., Eskalen, A., and Gubler, W. D. 2005. Teleomorph formation of Phaeoacremonium aleophilum, cause of esca and grapevine decline in California. Plant Dis. 89:177-184.
29. Rooney-Latham, S., Eskalen, A., Gubler, W Harrington, T. C., and McNew, D. 2004. Further investigations into the first report of the teleomorph of Phaeoacremonium aleophilum. Phytopathol. Mediterr. 43:145.

30. Scheck, H. S., Vasquez, S. J., Fogle, D., and Gubler, W. D. 1998. Grape growers report losses to black foot and grapevine decline. Calif. Agric. 52(4):19-23.

31. Scheck, H. S., Vasquez, S. J., Gubler, W. D., and Fogle, D. 1998. Young grapevine decline in California. Practical Winery and Vineyard (May/June):32-38.

32. Tulasne, L. R., and Tulasne, C. 1863. Selecta Fungorum carpologia. Vol. 2. Paris. Translated by W. B. Grove, 1931. Oxford University Press, Oxford.

33. White, T. J., Bruns, T., Lee, S., and Taylor, J. W. 1990. Amplification and direct sequencing of fungal ribosomal RNA genes for phylogenetics. Pages 315-322 in: PCR Protocols: A Sequencing Guide to Methods and Applications. M. A. Innis, D. H. Gefland, J. J. Sninsky, and T. J. White, eds. Academic Press, San Diego, CA.

34. Whiteman S. A., Jaspers, M. V., Stewart, A., and Ridgway, H. J. 2004. Identification of potential sources of Phaeomoniella chlamydospora in grapevine propagation material. Phytopathol. Mediterr. 43:152. 